\title{
Is it Really Necessary to Analyze Hundreds of Genes to Determine the Window of Implantation?
}

\author{
Almena López-Luna ${ }^{1,2}$, Dinorah Hernández-Melchor ${ }^{1,2}$ and Esther López-Bayghen ${ }^{2 *}$ \\ ${ }^{1}$ Laboratorio de Investigación y Diagnóstico Molecular, Instituto de Infertilidad y Genética SC, Ingenes, Mexico \\ ${ }^{2}$ Departamento de Toxicología, Cinvestav-IPN, México, DF, México
}

Submission: March 16, 2018; Published: April 06, 2018

"Corresponding author: Esther López-Bayghen, Departmento de Toxicologia, Laboratorio de Investigación y Diagnóstico Molecular, Mexico, Tel: +52555747-3800; ext. 5486; Fax:+52555747-3395; Email: ebayghen@cinvestav.mx

\section{Opinion}

Microarray technology enables researchers to analyze a large number of genes; this technique is useful in multiple fields such as genetics, toxicology, and pharmacology, among others. It provides a great amount of information and it has been used as a diagnostic tool of multiple diseases. In the field of assisted reproductive medicine this technology has been a promising approach to predict the window of implantation (WOI), being the most representative, the Endometrial Receptivity Array (ERA®), developed in 2009 by Diaz- Gimeno and collaborators [1] and patented by IGENOMIX, now offered under request. It detects the unique transcriptomic signature of endometrial receptivity by analyzing 238 differentially expressed genes in order to predict the window of implantation (WOI). The endometrial biopsy samples should be taken from the uterine fundus during the theoretical WOI $(\mathrm{LH}+7$ for natural cycles or $\mathrm{P}+5$ for hormone replacement therapy cycles), they must weigh about 70 milligrams and be sent to the company for processing. After analysis, the result will determine the patient as receptive or nonreceptive, if receptive, embryo transference may be scheduled the same day of sample taking in a later cycle. If non- receptive, the WOI of that specific patient could be displaced and another ERA test would be necessary to determine the specific time of her WOI. Although this technique has proved to be useful as a clinical diagnostic tool in reproductive medicine, it also entails technical limitations. First of all, the procedure to obtain the endometrial biopsy sample is to some extent, invasive. Furthermore, because of the timing at which it is collected, the test results would only be useful in a later cycle, extending the time in which the patient undergoes treatment and making the whole protocol more expensive. In addition, the use of microarray technology elevates test prices, making it unaffordable for some patients.

Given the importance of endometrial receptivity in pregnancy success, a more affordable, accessible, and efficient method is required. Due to this need, the goal of finding an improved method that provides the same receptivity information has been set. Furthermore, the need of a less invasive method is so imperative that even the IGENOMIX research group is looking for a more suitable solution. In an ongoing study presented at the ASRM Scientific Meeting 2017 [2], they displayed the endometrial liquid biopsy (ELB) as a potential alternative to the traditional sampling to perform the ERA analysis.

A major concern of smaller biopsies is whether they can provide sufficient amount of Nucleic to actually determine the transcriptomic signature of the WOI. However, is it really necessary to analyze hundreds of genes? Key genes associated with endometrial receptivity are differentially expressed during the endometrial cycle. When selected properly, monitoring the expression of a few genes could provide the same information that microarrays provide regarding receptivity. For instance, a study performed by our research group [3] demonstrated that it is possible to determine a transcriptional profile via RT-qPCR from cannula-isolated endometrial cells. In this method a cannula is introduced through the cervix in the day of transference ensuring it makes contact with the endometrium using ultrasonography guidance and then it is washed in PBS to obtain a cellular suspension.

Although the identity of the cells remains questionable, if successful, this less invasive method could be used to monitor receptivity, determine the WOI and personalize embryo transference in an ongoing cycle. In order to achieve this, some improvements are required: first, the selection of genes that have representative expression changes throughout the cycle is critical in order to determine in which stage each patient is set. Second, since the amount of recovered cells is limited, the extraction method should be efficient enough to isolate sufficient RNA to amplify a set of at least ten genes. Finally, the most important factor would be the timing in which the sample must be taken in order to successfully synchronize the protocol 
of sampling, its processing, and the opportune determination of the WOI to decrease the incidence of implantation failure.

In conclusion, although a functional method for determination of receptivity is already on the market, methods based on smaller transcriptional profiles will be able to determine the individual WOI with the a good accuracy close to that obtained using the entire transcriptomic signature, while being less invasive and more affordable.

\section{References}

1. Díaz-Gimeno P, Horcajadas JA, Martínez-Conejero JA, Esteban FJ, Alamá P, et al. (2011) A genomic diagnostic tool for human endometrialreceptivity based on the transcriptomic signature. Fertil Steril 95(1): 50-60.

2. Vilella F, Bolumar D, Blesa D, Clemente-Ciscar M, Rincon A, et al. (2017) Endometrial fluid transcriptomics as a new non-invasive diagnostic method of uterine receptivity. Fertility and Sterility 108(3): e48.

3. Camargo-Diaz F, Garcia V, Ocampo-Barcenas A, Gonzalez-Marquez H, Lopez Bayghen E (2017) Colony stimulating factor-1and leukemia inhibitor factor expression from current-cycle cannula isolated endometrial cells are associated with increased endometrial receptivity and pregnancy. BMC Womens Health 17(1): 63.

\section{Your next submission with Juniper Publishers will reach you the below assets}

- Quality Editorial service

- Swift Peer Review

- Reprints availability

- E-prints Service

- Manuscript Podcast for convenient understanding

- Global attainment for your research

- Manuscript accessibility in different formats

( Pdf, E-pub, Full Text, Audio)

- Unceasing customer service

Track the below URL for one-step submission https://juniperpublishers.com/online-submission.php 